\title{
An Exploratory Study of the Awareness and Accessibility of Microinsurance Products in Selected Insurance Companies in Lagos, Nigeria
}

\author{
Sunday Stephen Ajemunigbohun \\ Insurance Unit, Department of Accounting and Finance, Lagos State University, P.M.B. 0001, LASU Post \\ Office, Ojo, Lagos, Nigeria \\ Email: insurancelecturerlasu2009@yahoo.com \\ Ademola, Sulaiman Oreshile (Corresponding Author) \\ Insurance Unit, Department of Accounting and Finance, Lagos State University, P.M.B. 0001, LASU Post \\ Office, Ojo, Lagos, Nigeria \\ Email: counsellor_ins@yahoo.com \\ Ayodele Samuel Iyun \\ Head, Engineering \& Telecoms Division \\ Custodian and Allied Insurance Company Limited, Custodian House, 16A Commercial Avenue, Sabo, Yaba, \\ Lagos, Nigeria. \\ Email:ayodeleiyun@yahoo.com
}

\begin{abstract}
Microinsurance is crucial for a developmental stride in Nigeria's insurance industry. This research therefore presents an investigation of the awareness and accessibility of microinsurance products with selected insurance firms a research ground for its empiricality. Essentially, two hypotheses were tested. They are to determine whether: (i) aggressive awareness drive towards microinsurance products has not been genuinely encouraged among insurance companies in Nigeria; and (ii) the accessibility of microinsurance products created by insurance companies have not significantly reflected in the lives of many insuring populace. The survey research design for this study was exploratory in nature. The study sample consisted of sixty (60) respondents from whom data were gathered through the use of an interview technique. A Kolmogorov-Smirnov technique was used for data analysis. The findings from the study revealed that awareness creation towards microinsurance products has been genuinely encouraged among insurance companies, while the accessibility has not yet reflected significantly in the lives of many insuring populace. The study thus recommends that adequate awareness, education and enlightenment programmes be introduced especially for low income earners. Also, Government should promote "financial literacy" through educational programmes using the mass media;Greater attention should be given to reducing operating cost and enhancing efficiencies amongst microinsurance service providers; and investment and continuous improvement in technology is highly essential for effective relationship management between customers and the insurance firms.
\end{abstract}

Keywords: Microinsurance products, awareness, accessibility, service providers, Lagos, Nigeria

\section{INTRODUCTION}

All households in emerging economies, whether good or bad are vulnerable to varying numbers of risks ranging from illness, disability, death, unemployment, crime, crop failure and destruction or even natural disaster. However, low-income households are less capable to prevent and mitigate risks than others, and in the event of shocks, they are also unable to cope with the effects, consequences and outcomes (Churchill, 2006). Paul (2009) adds that risk and vulnerability to risk are fundamental causes of underdevelopment and that shocks in the shape of unforeseen misfortunes leading to loss of income and productive potentials, typically coerce poor individuals exposed to them to dispose of productive assets, which may further force them to reduce productivity, lower income and greater susceptibility in the future - a process he called the poverty-vulnerability vicious circle. Additionally, the expectation of such shocks motivates the vulnerable to invest their resources in low-yield activities, such as production of drought-resistant subsistence crops to safeguard themselves from these shocks and thus depresses the potential income of the poor far below what would be if they were not exposed to these shocks. Hence for these reasons, it is obvious and evident that the costs of risks to the livelihood of low-income households are severe; they are more likely to go through a significant reduction in wellbeing upon the occurrence of a shock (World Bank, 2001).

In the absence of insurance, poor people often combine resources from multiple sources to meet expenses for all unanticipated shocks (Epetimehin \& Odunaike, 2011). However, these resources are usually not sufficient to adequately cover their losses and over time they become stressed and over-utilized, less accessible 
and more costly, therefore, further reducing the ability of the poor to manage risks. Therefore, an indepth understanding of this reactive mode is a starting point in thinking about insurance for low-income households.

Daniel (2012) opines that the low-income bracket of the Nigerian economy is vulnerable to risk such as illness, death, accidents, damage to property to mention a few, with devastating consequences without a cushion to reduce the financial strain, owing to the non-existing or inadequate safety nets from the government, thus opening a window of opportunities for microinsurance. In the developed economies, insurance is regarded as an integral part of the financial and social structure of the economy, such that some forms of cover are mandatory in law and in these economies, the need for such safety nets is much greater, especially at the poorest levels where vulnerability to risks is much greater and there are fewer capabilities available to recover from a large loss (Aliero \& Shuaib, 2011).

In Nigeria, majority do not understand the concept of insurance, let alone the terms and conditions of an insurance contract. There is also the negative attitude to pay in advance for a service they may never receive (Cohen \& Sebstad, 2006). It thus appears that education on insurance or promoting financial literacy is one of the crucial aspects that is not popular in the Nigerian case and where providers of microinsurance should engage. Microinsurance therefore is yet to find a common place in Nigeria where majority of her population live below \$2 per day (Yoseph, 2010). Hence the need for microinsurance providers to understand the low-income market and device low-premium insurance products for this category of people. Additionally, the level of participation in microinsurance service provision and its awareness to the public by Nigerian insurers over the years is not aggressive and not encouraging- the average Nigerian does not understand what microinsurance mean, its benefits and how to access its products. Finally, microinsurance products are also designed to protect assets and property but unfortunately, low per capita income of vast majority of Nigerians results in low level property ownership and therefore a resultant failure to purchase microinsurance products.

Microinsurance is the protection of low-income people against specific perils in exchange for regular premium payments proportionate to the likelihood and cost of risk involved (Churchill, 2006). It is referred to as a device designed to protect against a set of predetermined risk relating primarily to business, health, agriculture and life (Banerjee, 2008). Bayer et al (2006) had earlier opined that microinsurance can break the cycle of poverty by providing low-income households, businesses, and farmers with access to after-disaster funds, thus protecting their livelihoods and providing reconstructuring. Therefore, insured households and firms will be credit worthy, able to invest in productive assets and higher-risk yield crops.

\section{Research questions}

To achieve the set objectives of this study, the following research questionswere considered:

i. What is the extent of awareness of the benefits that are obtainable from transacting microinsurance products/ businesses among Nigeria's insurance companies?

ii. What is the extent of awareness of the existence and availability of microinsurance products among low-income earners in Nigeria?

iii. Are many Nigerians aware of the accessibility of microinsurance products?

iv. To what extent have Nigeria's insurance companies harness untapped opportunities and benefits that abound in microinsurance businesses?

\section{LITERATURE REVIEW}

\section{Microinsurance: theoretical and empirical underpins}

Numerous researchers, authors, organizations and public authorities have inquired and expended huge sums of money, time and other valuable resources to proffer a reliable solution and medium of protecting the impoverished population by ensuring they have and enjoy sustainable livelihood and standard of living after a disaster happens. It is now a general believe that microinsurance holds out the panacea of breaking a part of the vicious circle that ties the poor to poverty and vulnerability (Morduch, 2004). This promise of microinsurance is becoming obvious at various levels as it stands to benefit the working poor, their service providers and more specifically contributing to economic development.

Churchill (2006) defines microinsurance as the financial protection for the un- and underserved against risk in exchange for a premium proportionate to the probability and cost of the insured risk. Banerjee (2006) opines that microinsurance policies offer protection against a set of predetermined risks relating primarily to business, health, agriculture and life. Yusuf and Mobolaji (2012) submit that microinsurance in simple parlance means insurance for the poor. Singh and Miglani (2011) had earlier posited that microinsurance is the use of insurance as an economic instrument at the micro (i.e. smaller than national) level of the society. They further explained that the use of the word "micro" connotes the small financial transaction that each insurance policy generates. Alexander et al (2002) and Singh and Miglani (2011) both agreed that microinsurance is synonymous to community-based financing arrangements including community health funds, mutual health organizations, rural health insurance and revolving health funds. 
Daniel (2008) sees microinsurance as the tool of microfinance designed to alleviate poor families and low income people from specific perils. Cohen et al (2003) add that microinsurance offers a valuable vehicle to reduce the vulnerability that confronts the poor while at the same time affording insurers and their agents the opportunity to expand and grow their market to include low-income households. Barnett et al (2008) acknowledge that microinsurance has the potential of being an "additional" risk transfer mechanism to reduce the vulnerability of the poor. Churchill (2006) and Morsink and Geurts (2011) stipulated that it is vital to note that the term "micro" insurance microinsurance refers to the target population and the context, instead of the risk carrier, the scope of the risk or the delivery channel. Holzmann (2001) argued that microinsurance is one of several microfinance services as microfinance institutions have been piloting microinsurance products recognizing that increased risk management products can protect their own and their clients' interests. Patel (2004) identified that microinsurance is an effective mechanism for reducing the vulnerability of the poor from the impact of disease, theft, disability, and other hazards as well as safeguarding the productive use of savings and credit facilities.

Cohen et al (2003) argued that for microinsurance to succeed, the products and services must be appropriate in terms of awareness, coverage, timeliness, affordability and accessibility. They argued further that getting the appropriate design is reliant upon the understanding of both the demand and supply side of microinsurance. Siegel et al (2001) had earlier mentioned that creating adequate awareness is one of the key factors that will ensure the success of microinsurance programmes because a major drive for microinsurance services is that most households have been outrightly excluded from existing insurance schemes due to (i) formal insurers have done little or nothing to reach out to those segments that are outside the mainstream formal economy (i.e. low-income households, rural households and informal sector) of the population; and (ii) the excluded segments lack the financial wherewithal and capacity to access formal insurance.

Accordingly, Tomchinsky (2008) opined that consumer awareness, education, marketing and complaint handling will certainly grow microinsurance. Tomchinsky submitted that the microinsurance sector is different in the sense that there is an ongoing herculane task of explaining the concept and benefits to the insured; creating awareness through pictorial posters and street treaties might be helpful in explaining the dynamics of microinsurance. Brown et al (2000) advised that before embarking and investing on creating awareness and enlightenment about microinsurance in terms of its benefits and accessibility, it is crucial to consider three questions regarding microinsurance; (i) do low-income households want assistance in reducing vulnerability to the risks to be covered by insurance?; (ii) is insurance considered the most appropriate financial service for providing protection?; and (iii) are clients willing, ready and able to pay a price at which the insurance can be delivered profitably? Dror et al (2012) posited that consumer education and awareness about microinsurance entails a systematic effort to teach risk management strategies and the benefits of insurance in order to promote the best risk management practice among low-income households. Arun and Steiner (2008) earlier identified that one of the major bottlenecks in the growth of microinsurance business in developing economies is the low level of experience and education of the target group with formal insurance.

Daniel (2008) mentioned that one of the crude benefits of operating microinsuranceis its ability to alleviate poor families and low-income people from specific risks. Abayomi (2010) posited that the emergence of microinsurance within the field of microfinance is an important development and this challenges the incapabilities of the poor to afford insurance. He argued that microinsurance is a combination of micro-savings, microfinance, and micro-credit; thus it serves the dual functions of a risk management and loss protection instrument. Jutting and Ahuja (2003) had earlier submitted that microinsurance is considered to play important role of financing tool to protect the poor from adverse financial consequences in the event of sickness or illness. Churchill (2008) was of the view that there is an alarming demand for social protection among the poor, therefore microinsurance in collaboration with micro-saving and micro-credit could go a long way in safeguarding this group from poverty trap and would be a crucial component of financial inclusion.

Devaux (2000) pondered that one of the benefits of microinsurance is that it promotes credit and savings to be used more productively on generating employment opportunities. Yoseph (2010) averred that microinsurance can serve as collateral for loans and working capital for medium and small enterprises businesses (MSMEs), encouraging more secured credit, entrepreneurship and innovation, thereby lifting the poor out of poverty. Churchill and Reinhard (2012) also argued that there are broad benefits derivable from the operations of microinsurance. These are (i) benefits to the working poor, where the potential contributions of microinsurance to breaking the cycle of poverty has both protective and productive roles; (ii) benefits to microinsurance providers in terms of providing them, especially more commercially and business-oriented organizations, opportunities to enter new markets or expand their services to an existing market. This connotes that microinsurance provides practitioners with a Bottom of Pyramid (BOP) strategy to effectively reach and serve the next generation policyholders today; (iii) benefits to the government in helping to achieve the various social protection objectives of the government which include expanding social protection, providing greater and better cover against the threats and effects of natural disaster and achieving public policy objectives. 


\section{Microinsurance products: distribution and accessibility}

Arun and Steiner (2008) opined that microinsurance providers worldwide offer basically four types of insurance which include life, health, accidental death and disability, and property insurance. Epetimehin and Odunaike (2011) argued that microinsurance is not a specific product or product line and that it is not limited to a specific provider type. They further enumerated five common microinsurance products in developing economies [such as life microinsurance, health microinsurance, disability microinsurance, agricultural microinsurance and catastrophic cover]. Yoseph (2010) had earlier observed that most microinsurance products are usually tailored with so much emphasis on health and life risks. In a survey conducted by SwissRe (2007) a total of 84 million people are covered under life microinsurance, 35 million people by health microinsurance, 36 million people by property microinsurance and 41 million people by accident and disability microinsurance. Ikupolati (2008) and Acha and Ukpong (2012)were of the opinion that the greatest obstacle for microinsurance is not even in the product design but rather in the actual delivery to and accessibility by the target market. They concluded that the models and techniques for achieving successful delivery and accessibility vary and is based on factors like organization of institutions and providers involved.

Tadesse and Brans (2012) pondered that for microinsurance products to be accessible, they must be affordable and exclusively relevant to clients' needs. They stressed that while concerted and successful efforts have been made by microinsurance providers to make their products offerings affordable, they are lacking in terms of tailoring these products around their customer needs and aspirations. They advised that microinsurance providers should strive to adopt the most efficient and effective between traditional supply-driven products or demand-driven products which entails market research and new product development. Cohen et al (2003) had hitherto opined that location often affects poor people's access to microinsurance programmes, especially in rural areas; the poor are further disadvantaged since lack of quality health care services severely undermine the potential for microinsurance.

Generally, there are four main techniques for distributing microinsurance products or services - the partner-agent model, the provider-driven model, the full-service model or (mutual model), and the communitybased model (Siegel et al, 2001; SwissRe, 2007; Aliero and Shuaib, 2011; Acha and Ukpong, 2012). Siegel et al (2001) posited that a major focus of the different delivery techniques over the years has been to deal with the question: how can we lower transaction cost and cost associated with information asymmetry? And that the current trend is the critical question, which bears the financial risks of the insurance agreement? In the partneragent model, a licensed insurer carries the risk and the microfinance institution (or other distributors) provides access to clients. In a full-service model, the scheme is in charge of everything, both the design and delivery to care providers to render services. The provider-driven model is similar to the full-service model; the provider is responsible for all the operations, design, delivery and other related services. In a study conducted by Obuvie (2010), the community-based model of delivering microinsurance services was identified as appropriate in the Nigerian case. Obuvie opined that this model provides a platform for microinsurance providers to develop products aimed at satisfying the peculiar needs of each individual community. It also affords community involvement, which apart from incorporating the "clients" in the management and operations, it also serves as an avenue of intimating the rural inhabitants on the importance and functions of insurance (Acha and Ukpong, 2012). Yoseph (2010) submitted that microinsurance can also be designed and distributed through conventional insurance companies, microfinance institutions, labour unions, NGOs, and large micro-credit institutions.

\section{Challenges of microinsurance growth and development in Nigeria}

Moller (2004) conducted a study on the quality of life in emerging economies with reference to South Africa. He found that income levels and social security schemes have been considered as important indicators of how qualitative life is. Moller's findings corroborate the vital role insurance plays in human life. Unfortunately, insurance services appear not to have been accepted willingly in developing countries. This low patronage of insurance services has triggered relative desires to find a lasting solution among practitioners and researchers. Additionally, microinsurance is an important instrument to alleviate poverty and the logic behind it is that it helps the poor and vulnerable to easily climb the economic ladder (Epetimehin and Odunaike, 2011). It is designed basically for the poor in developing economies who are either self-employed or employed in medium or small firms and do not have the financial resources to access formal insurance products (Acha and Ukpong, 2012; Churchill and Reinhard, 2012; Yusuf and Mobolaji, 2012).

According to IMF (2013) the insurance sector is an underdeveloped part of the Nigerian financial sector accounting for less than 2 percent of GDP in assets. Omar (2007) had earlier assessed the Nigerian consumers' attitude towards insurance patronage and found that there is gross misconduct, lack of trust and confidence in the Nigerian insurance industry. In an earlier study of insurance penetration in Nigeria conducted by Yusuf (2006), it was discovered that an interest-free insurance scheme received the patronage of Muslim population. IMF (2013) reported that insurance penetration by the Nigerian insurance industry is low; the Nigerian Benchmark Insurance Penetration (BMIP) value indicates that the industry is underdeveloped with only 43 percent of the world 
average insurance penetration. SwissRe (2013) also published that Nigeria is ranked $58^{\text {th }}$ in terms of insurance density and penetration out of 59 emerging insurance markets. Ikupolati (2008) averred that the greatest challenge confronting the growth of microinsurance in Nigeria is the actual delivery to clients. Abayomi (2010) added that microinsurance in Nigeria in terms of growth and popularity is hampered by insufficient microinsurance models capable and reliable in fitting into the microfinance clientele models as well as dearth of highly specialized products to serve the needs of different groups and societies faced with varying risks.

Epetimehin and Odunaike (2011) reiterated that the distribution systems of most microinsurance providers in Nigeria are not designed to serve the low income market. They added that target market lack of information, awareness and understanding have deeply affected the demand for microinsurance services. Onuoha (2012)submits that the major challenge that has affected the growth of microinsurance in Nigeria is that insurance practitioners have never spent time and resources to conduct a comprehensive research on who the customers are, what they really want, and how they can be served better. Duru (2012) argues that creating the correct channels for distributing microinsurance products is a major challenge militating against the growth and popularity of microinsurance in Nigeria. Daniel (2012) enumerated some regulatory challenges forestalling the growth of microinsurance in Nigeria, such as ineffective financial market infrastructure, rigid insurance law, low insurance education and awareness, big ticket account focus of commercial insurers and inadequate statistical data on microinsurance. Duru (2012) reaffirmed that in insurance business, trust is key, and that failure to ensure its continued sustenance will impede the growth and advancement of microinsurance. Duru opined that operators need to earn, retain and sustain customer's confidence and trust to remain in business.

\section{RESEARCH METHODS}

This study made use of an interview survey method in gathering data. The interview method involves questioning and discussing issues with insurance practitioners with respect to microinsurance practices. This technique has been seen to be very useful in gathering such data which would likely not be accessible using techniques such as observation or questionnaire (Blaxter, Hughes \& Tight, 2006). The interview is scheduled and structured; and advantageous because of its ability to generally produce fewer incomplete questionnaires, achieve higher completion rates than self-administered questionnaires, and more effective for complicated issues (Babbie, 2005; Osuala, 2005). The views of respective respondents were coded to improve the completion of the interview scheduled which was drawn using a Likert-type scale measurement of 'Strongly Agree', 'Partially Agree', 'Not Agree'.

The research adopted a survey design and that which was exploratory in nature. The involvement of survey design was because of its ability to predict behaviour and help in gathering the same information about all the cases in a sample (Aldridge \& Levine, 2001; Borden \&Abott, 2002). This study employed a judgmental sampling technique because it helped select the unit(s) to be observed on the basis of the researchers' knowledge or judgement of the population, its element and purpose of the study (Babbie, 2005). In a bid to gather relevant information for the study, a pre-determined interview schedule was designed to few selected insurance officers, which informed the selection of the surveyed companies. This study thus chooses 15 insurance companies within which 4 officers were interview per company (i.e. $4 \times 15$ ) bringing the respondents to 60 .

\section{Test of hypotheses}

The researchers came up with two hypotheses that help to give a clear direction for the research process. A test of hypothesis has been described as a statistical technique that uses sample data to ascertain a hypothesis about the parameter of a population (Gravetter\&Wallnau, 2000).

H1: Aggressive awareness drive towards microinsurance products has not been genuinely encouraged among insurance companies in Nigeria

H2: The accessibility of microinsurance products created by insurance companies have not significantly reflected in the lives of many insuring populace

The testing technique used to test the formulated hypotheses was a Kolmogorov-Smirnov. The KolmogorovSmirnov technique is a non-parametric tool suitable to test the goodness of fit to an ordinal data; and moreso, help to compared a theoretical distribution with an observed distribution of samples. The Kolmogorov-Smirnov test is described as follows:

$D=\max \left|F_{0}(x)-S_{n}(x)\right|$

Where $\mathrm{F}$ is described as the number of observations, $\mathrm{F}_{0}(\mathrm{X})$ is defined as a specified cumulative frequency distribution under the null hypothesis $\left(\mathrm{H}_{0}\right)$ for any value of $\mathrm{X}$ and the proportion of circumstances expected to have scores equal to or less than $X$; while $S_{n}(X)$ is said to be described as an observed cumulative frequency distribution of a random sample $\mathrm{N}$ observations where $\mathrm{X}$ is any possible score. The $\mathrm{H}_{0}$ is the specification of the null hypothesis (which is a representation of $\mathrm{H}_{1}$ and $\mathrm{H}_{2}$ ). The null hypotheses are such that is set up as a logical counterpart of the alternative hypotheses such that if the null hypotheses are untrue, the alternative hypotheses must be true (Pagano, 1994). The decision rule is such that null hypotheses $\left(\mathrm{H}_{0}\right)$ will be rejected once the 
calculated D (i.e. $\left.\mathrm{D}_{\text {cal }}\right)$ is greater than the tabulated $\mathrm{D}\left(\mathrm{D}_{\mathrm{tab}}\right)$ under the deviation level of 0.05 . The tabulated $\mathrm{D}$ from the Kolmogorov-Smirnov test table is always represented by $(\alpha / \sqrt{N})$; where $\alpha=1.36$ and $\mathrm{N}$ is described as the number of observation. The critical value of $\mathrm{D}$ must be such represented as $\mathrm{N}>35$ (i.e. large samples).

RESULTS AND DISCUSSION

Table 1.Responses to Hypothesis 1 (simple frequency table)

Strongly agree Partially agree Not agree Total

$\begin{array}{lllll}\text { Responses } & 03 & 19 & 38 & 60\end{array}$

Table 2: Kolmogorov-Smirnov frequency table for Hypothesis 1

Rank of views of respondents

Hypothesis Strongly agree Partially agree Not agree

F $=$ Aggressive awareness drive towards

microinsurance products has not been 03

19

38

genuinely encouraged among insurance

companies in Nigeria

$F_{0}(X)=$ Theoretical cumulative distribution

$0.3333 \quad 0.6666$

1

$\mathrm{S}_{\mathrm{n}}(\mathrm{X})=$ Cumulative distribution of observed
Choices
0.0500
0.3666
1

$\left|\mathbf{F}_{0}(\mathbf{X})-\mathbf{S}_{\mathbf{n}}(\mathbf{X})\right|$

0.2833

0.3000

0

Source: Data Analysis, 2013

Hypothesis 1: Aggressive awareness drive towards microinsurance products has not been genuinely encouraged among insurance companies in Nigeria. From the Kolmogorov-Smirnov frequency table for the hypothesis, the calculated $\mathrm{D}$ value is the point of the greatest divergence between the cumulative observed and cumulative theoretical distribution, which is 0.30000 . The tabulated D from the Kolmogorov-Smirnov test table at $(\alpha / \sqrt{ } \mathrm{N})=$ $1.36 / \sqrt{ } 60$ is given as:

$\mathrm{D}=\alpha / \sqrt{ } \mathrm{N}=1.36 / \sqrt{ } 60=1.36 / 7.746=0.1755$

In this case, since calculated $\mathrm{D}$ value $(0.3000)$ exceeds the critical value of 0.1755 , the null hypothesis $\left(\mathrm{H}_{0}\right)$ stating that aggressive awareness drive towards microinsurance products has not been genuinely encouraged among insurance companies in Nigeria is rejected at $\alpha=0.05$ (see table 1). This, then, implies that aggressive awareness drive towards microinsurance products has been genuinely encouraged among insurance companies in Nigeria. This result confirms the earlier study of Tomchinsky (2008); Cohen et al. (2003); Siegel et al. (2000); among others, who agitated for proper awareness, education and enlightenment of microinsurance products among households. 
Table 3: Responses to Hypothesis 2 (simple frequency table)

\begin{tabular}{lccccc}
\hline Strongly agree & Partially agree & Not agree & Total & & \\
\hline Responses & 32 & 17 & 11 & 60 \\
\hline
\end{tabular}

Table 4: Kolmogorov-Smirnov frequency table for Hypothesis 2

Rank of views of respondents

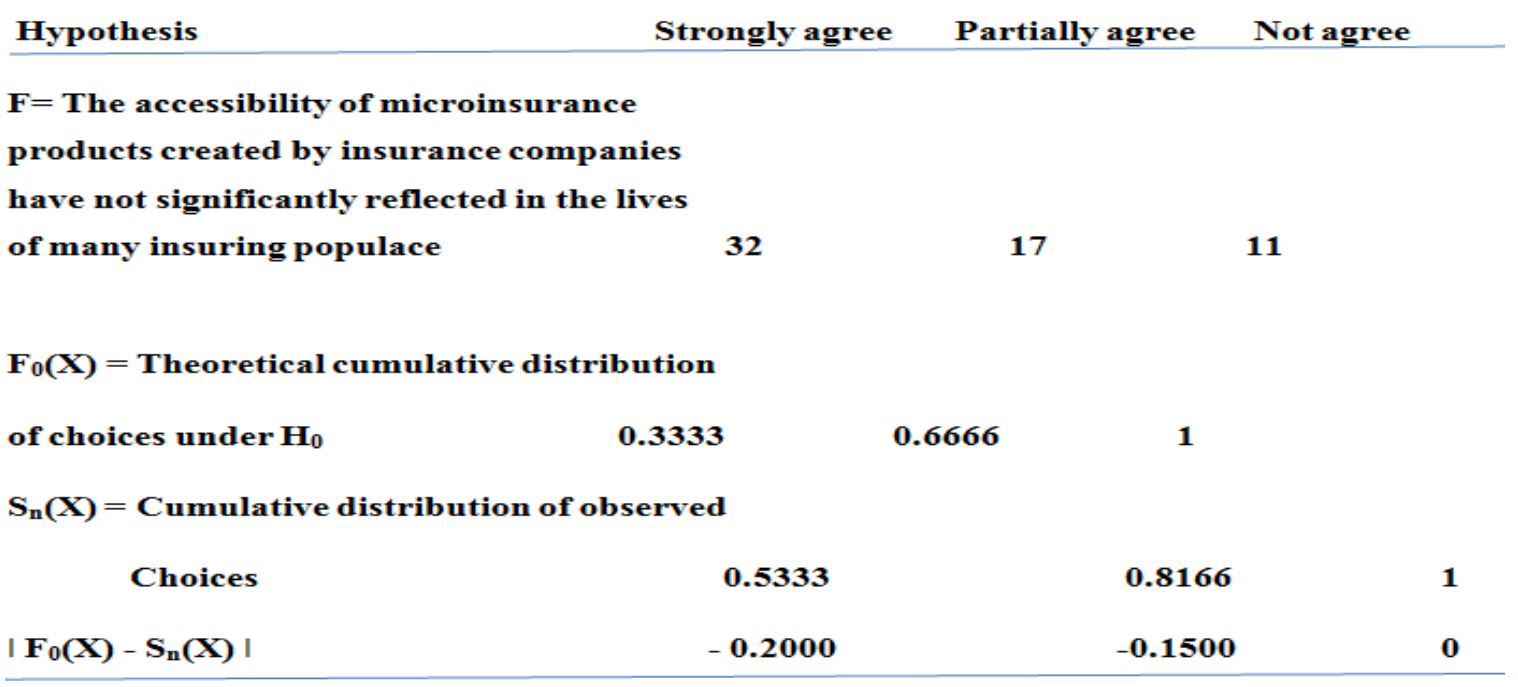

Source: Data Analysis, 2013

Hypothesis 2: The accessibility of microinsurance products created by insurance companies in Nigeria has not significantly reflected in the lives of many insuring populace. From the Kolmogorov-Smirnov frequency table for the hypothesis, the calculated D value is the point of greatest divergence between the cumulative observed and cumulative theoretical distribution, which is -0.1500 . The tabulated D from the Kolmogorov-Smirnov test table at $\mathrm{D}=\alpha / \sqrt{\mathrm{N}}=1.36 / \sqrt{ } 60=1.36 / 7.746=0.1755$

In this case, since calculated $\mathrm{D}$ value $(-0.1500)$ is less than the critical value of 0.1755 , the null hypothesis $\left(\mathrm{H}_{0}\right)$ stating that the accessibility of microinsurance products created by insurance companies in Nigeria has not significantly reflected in the lives of many insuring populace is accepted at $\alpha=0.05$ (see table 4). This, therefore, implies that the alternative hypothesis stating that the accessibility of microinsurance products created by insurance companies in Nigeria has significantly reflected in the lives of many insuring populace is rejected. These results, according to respondents' view, have been associated with certain factors such as: ignorance, low income, lack of trust, and low level of financial literacy. The result is in consistent with earlierstudy [such asChurchill \& Reinhard, 2012; Duru, 2012; Yoseph, 2010; Omar, 2007; among others].

\section{CONCLUSION, RECOMMENDATIONS AND FUTURE STUDIES}

This study attempts to explore the awareness and accessibility of Microinsurance products among selected insurance firms. However, it is evident, with the vast population of Nigeria, that microinsurance presents a viable market that is yet untapped by the nation's insurance service providers. This studyis consistent with earlier studies [such as Churchill and Reinhard (2012), Yoseph (2010), Devaux (2000, among others]; it presents evidence that Microinsurance not only provides a platform for the insurance companies to enlarge their frontiers and increase their market share (increased premium), it also provides the insurance industry as a whole the opportunity to enhance insurance penetration and insurance density amongst the populace most especially rural dwellers. The market is also veritable tool in creating additional employments [.i.e. agents, specialists etc.]. Findings from this study thus gave supporting evidence that greater investment in awareness creation and providing platforms for accessibility are sine qua non for enhancing widespread knowledge of microinsurance service providers as well as creating greater patronage for microinsurance products.

Conclusively, microinsurance providersneed to make sure that they design tailor-made products that are relevant to the need of the market, distributed through a channel that is convenient for the target person, while also fostering the trust of the low income market in insurance and the insurance industry as a whole.

With an indepth consideration of the findings, the study recommends therefore that:

i. Highly personalized microinsurance products be targeted towards satisfying the needs of each 
individual, group or community;

ii. Adequate awareness, education and enlightenment programmes be encouraged especially for low income earners to attract them to microinsurance offerings and products;

iii. Insurance business in Nigeria faces the challenge of trust between the insurer and the insured and this hampers and often frustrates their relationship. Hence the need for microinsurance providers to imbibe utmost good faith in the course of their operations to foster trust;

iv. Microinsurance providers should implement flexible payment plans for participants. This may improve participation;

v. Microfinance houses should be encouraged and sponsored to venture into microinsurance as a means of mitigating vulnerability and poverty among the low income class;

vi. Government should promote "financial literacy" through educational programmes using the mass media;

vii. A Micro Insurance Agency could be established either by the government or insurers in Nigeria. This agency will plan to incorporate and implement an insurance education curriculum, design and educate potential and existing policyholders on the features and benefits of insurance products and the role of insurance in relation to loans and savings products;

viii. Greater attention should be given to reducing operating cost and enhancing efficiencies amongst microinsurance service providers; and

ix. Investment and continuous improvement in technology is highly essential for effective relationship management between customers and the insurance firms.

This study suggests that future researches should tailor their efforts towards areas that borders especially on the demand side of microinsurance such as behavioural pattern of demand for microinsurance, microinsurance marketing research, microinsurance post-purchasing decisions and so on. Additionally, research efforts could be concentrated in microinsurance distribution models that could enhance greater accessibility and awareness among the insuring populace.

\section{References}

1. Abayomi, A. (2010). Micro-Enterprise Development: Developing Microinsurance in Nigeria. Vanguard Newspaper Online.

2. Acha, I., and Ukong, M.S. (2012). Microinsurance: A Veritable Product Diversification Option for Microfinance Institutions in Nigeria. Research Journal of Finance and Accounting, Vol.3, NO. 8, Pp. 78-85.

3. Alexander, S., Carrin, G., Dror, D., Jakab, M., William, H. and Arhin-Teenkrung, D. (2002). Effectiveness of Community Health Financing in Meeting Cost of Illness. Bulletin of the World Health Organization, Geneva: WHO, 80(2), Pp. 143-150.

4. Aliero, H. M., and Shuaibu, M. (2011). The Prospects of Micro-Insurance in the Rural Areas of Nigeria. European Scientific Journal, 8(3), 66-76.

5. Arun, T. and Steiner, S. (2008). Micro Insurance in the Context of Social Protection. Manchester: Brooks World Poverty Institute.

6. Banerjee, A. (2008). Technology Indispensable in Marketing Microinsurance Accessible in Asia Insurance Review, online portal of 31 InfoTech. Retrieved on 20/11/2012 by 11:00am. www.asiainsurancereview.com.

7. Barnett, B.J., Barret, C.B., Skees, J.R. (2008). Poverty Traps and Index-based Risk Transfer Products. World Development, Vol. 36, Pp. 1766-1785.

8. Bayer, J., Mechler, R., and Peppiatt, D. (2006). Disaster Insurance for the Poor: A Review of MicroInsurance for National Disaster Risk in Developing Countries. A Prevention/IIASA Study Sponsored by IFRC.

9. Brown, N., Green, C., and Lindquist, G. (2000). A Cautionary Note for Microfinance Institutions and Donors Considering Developing Microinsurance Products. A Paper prepared for USAID Microenterprise Best Practices Project USAID: Washington, D.C. www.mip.org.

10. Churchill, C. (Ed.) (2006). Protecting the Poor. A Microinsurance Compendium, Geneva, Switzerland: International Labour Office.

11. Churchill, C. and Reinhard, D. (2012). Benefits of Microinsurance. In C. Churchill and M. Matul (Eds.), Protecting the Poor: A Microinsurance Compendium, Vol. 2, Pp. 1-5. Geneva, Switzerland: International Labour Office.

12. Cohen, M. and Sebstad, J. (2006). The Demand for Microinsurance. In C. Churchill (Ed), Protecting the Poor: A Microinsurance Compendium, Vol. 2, Pp. 1-5. Geneva, Switzerland: International Labour Office.

13. Cohen, M., Mc Cord, J.M., and Sebstad, J. (2003). Reducing Vulnerability: The Demand for and Supply of Microinsurance in East Africa. Nairobi: Micro-Save Initiative.

14. Daniel, F (2008). Microinsurance as Bedrock for Social Economic Development of West Africa. A paper Presented at the WAICA Educational Conference 10th - 11th November, 2008. Lagos, Nigeria.

15. Daniel, F. (2012). Challenges of Microinsurance and Regulatory Response. At the High-Level Seminar on 
Micro insurance Regulation for Supervisory Authorities in Khartoum, Sudan, 31st May, Pp. 2-3. Nigeria: National Insurance Commission.

16. Dror, I., Dalal, A., and Matul, M. (2012). Emerging Practices in Consumer Education on Risk Management and Insurance. In C. Churchill and M. Matul (Eds.), Protecting the Poor: A Microinsurance Compendium (Vol. 2), Pp. 286-298. Geneva, Switzerland: International Labour Office.

17. Duru, N. (2012). Making Microinsurance Work in Nigeria: Microinsurance News, July 25, 2012, Thisday Newspapers Online.

18. Epetimehin, F.M., and Odunaike, F., (2011). Micro Insurance: A Risk Pooling Instrument for Protection of Low Income Households. Journal of Business and Organizational Development, Vol.3, Pp. 60-74.

19. Holzmann, R. (2001). Risk and Vulnerability: The Forward Looking Role of Social Protection in a Globalizing World. Social Protection Discussion Paper (No 0109). Washington: World Bank.

20. Ikupolati, M. (2008). The Practice of Microinsurance in West Africa: The Journey So Far. A Paper Delivered at WAICA Educational Conference. Lagos, Nigeria.

21. IMF (2013). Insurance Core Principles: Financial Sector Assessment Program Update. Washington: IMF.

22. Jutting, J. and Ahuja, R. (2003). Are the Poor too Poor to Demand Health Insurance? Journal of Microfinance, Vol. 6, No.13, pp. 26-30.

23. Kinshanjit, B. and Krishan, J (2000). Microfinance: Emerging Challenges. New Delhi: Tata McGraw Hill Publishing Co. Ltd.

24. Moller, V. (2004). Researching Quality of Life in a Developing Country: Lesson from South Africa. Retrieved 05/12/2012 from http://www.well.dev.org.uk/news/hause-pdfs/moller-hause-full-pdf.

25. Morduch, J. (2004). Microinsurance: The Next Revolution? In A. Banerjee, R. Benabon, and D. Mukherjee (Eds.), What Have We Learned About Poverty? Pp. 1-19. New York University. New York: Oxford University Press.

26. Morsink, K and Geurts, P. (2011). Informal Trust Building Factors and the Demand for Microinsurance. A Paper Delivered at the $7^{\text {th }}$ International Microinsurance Conference, Rio de Janeiro, Brazil, Pp. 1-27.

27. Obuvie, K. (2010) in Chang, C. (2010) Micro-capital Brief: The Promise of Microinsurance in Nigeria. http://www.microcapital.org/microfinanceuniverse/tiki.html.

28. Omar, O.E. (2007). The Retailing of Life Insurance in Nigeria: An Assessment of Consumers' Attitudes. Journal of Retail Marketing Management Research, Vol.1, No.1, Pp. 41-47.

29. Onuoha, R. (2012). Developing Microinsurance in Nigeria: Microfinance Africa, October 3, 2012. Vanguard Newspapers Online.

30. Patel, S. (2004). Insurance and Poverty Alleviation: The Cooperative Advantage. London: ICMIF

31. Paul, M. (2009). Assessing the Success of Micro Insurance Programmes in meeting the insurance needs of the poor. DESA Working Paper No. 84, USA: United Nations Secretariat.

32. Siegel, P.B., Alwang, J. and Canagarajah, S. (2001). Viewing Microinsurance as a Social Risk Management Instrument. A Social Protection discussion paper No. 0116, Washington: World Bank.

33. Singh, P.P., and Miglani, S. (2011). Microinsurance Schemes: Awareness and Future prospects among Labour Class. A paper delivered at the conference on inclusive and sustainable Growth, Role of Industry, Government and Society: Institute of Management Technology.

34. SwissRe (2013). World Insurance (2012). Progressing on the Long and Warding Road to Recovery. Switzerland: SwissRe Ltd.

35. Tadesse, M. and Brans, V.M., (2012). Risk, Coping Mechanisms, and Factors in the Demand for Microinsurance in Ethiopia. Journal of Economics and International Finance. Vol. 4, No. 4, Pp. 79-91.

36. Tomchinsky, G. (2008). Introduction to Microinsurance Historical Perspective. A Paper Delivered at the $4^{\text {th }}$ International Microinsurance Conference, Cartagena, Colombia.

37. World Bank (2001). Attacking Poverty: World Development Report 2000/01. Washington DC: World Bank. 38. Yoseph, A. (2010). Micro-Insurance: A Tool for Growth and Development of the African Insurance Industry. International Insurance Conference, ILO Regional Office for Africa, Lagos: ILO.

39. Yusuf, T.O., and Mobolaji, A.I. (2012). The Role of Islamic Microinsurance in Economic Growth and Development: The Nigerian Experience: A case study of Al-Barakah Microfinance Bank, Lagos. International Journal of Business and Commerce, Vol.1, No.10, Pp. 106-122.

40. Yusuf, T.O., Gbadamosi, A. and Hamadu, D. (2009). Attitudes of Nigerians towards Insurance Services: An Empirical Study. African Journal of Accounting, Economics, Finance and Banking Research, Vol.4, No.4. Pp. 34-46. 